\title{
PENGARUH LINGKUNGAN ORGANISASI DAN KOMPETENSI PROFESIONAL TERHADAP EFEKTIVITAS MANAJERIAL KEPALA SEKOLAH
}

\section{THE INFLUENCES OF ORGANIZATIONAL ENVIRONMENT AND PROFESSIONAL COMPETENCE TO PRINCIPAL'S MANAGERIAL EFFECTIVENESS}

\author{
Neng Nurhemah \\ Sekolah Menengah Atas Negeri 2 Kota Tangerang Selatan \\ Jalan Raya Puspiptek Muncul, Setu, Tangerang Selatan \\ e-mail:nengnurhemah@yahoo.com
}

Diterima: 19 Mei 2017; dikembalikan untuk direvisi: 16 Juni 2017; disetujui: 14 Juli 2017

\begin{abstract}
ABSTRAK.
Tujuan penelitian ini adalah untuk mengkaji pengaruh lingkungan organisasi dan kompetensi profesional terhadap efektivitas manajerial kepala sekolah. Penelitian ini menggunakan pendekatan analisis jalur dengan metode survei. Penelitian dilaksanakan pada Sekolah Menengah Pertama di Kota Tangerang Selatan.Sampel penelitian sebanyak 102 kepala sekolah yang diambil secara acak. Analisis data menggunakan statistik deskriptif dan model persamaan struktural (SEM) yang diolah dengan program LISREL 8.0. Hasil penelitian menunjukkan bahwa lingkungan organisasi dengan t-hitung $(2,128)>$ t-tabel $(1,665)$ dan kompetensi profesional dengan t-hitung $(3,959)>$ t-tabel $(1,665)$ memiliki pengaruh signifikan terhadap efektivitas manajerial kepala sekolah. Oleh karena itu, untuk meningkatkan efektivitas manajerial kepala sekolah, lingkungan organisasi dan kompetensi profesional perlu ditingkatkan.
\end{abstract}

Kata kunci: efektivitas manajerial, lingkungan organisasi dan kompetensi profesional

\section{ABSTRACT}

The aims of this research is to examine the influence of organization environment and proffesional competence through the efdectiveness of principal's managerial. This study implements the approach of line analysis using survey method. This research conducted at Junior High School in South Tangerang. The sample of this research are 102 principals which is choosen randomly. The data analysis of this research used descriptive statistic and the equation structural model (SEM) which is processed by using the Progran of LISREL 8.0. The result of this study shows that organization environment with t-hitung (2.128) $>t$-tabel (1.665) and the proffesional comoetence with t-hitung (3.959) > t-tabel (1.665) has influence significantly through the effectiveness of principals' managerial. So that, to improve the effectiveness of principals 'managerial and proffesional competence should be increased well.

Keywords: managerial effectiveness, organizational environment and professional competence 


\section{PENDAHULUAN}

Seiring dengan otonomi daerahdan dilanjutkan dengan otonomi pendidikan; maka tanggungjawab pengelolaan pendidikan sudah tidak lagi terpaku pada pemerintah pusat. Oleh karena itu, pemerintah daerah memiliki tanggungjawab untuk mengembangkan pendidikan di wilayahnya masing-masing.

Berhasil tidaknya sebuah lembaga pendidikan dalam mencetak sumber daya manusia berkualitas tergantung oleh banyak faktor, salah satunya adalah faktor efektivitas manajerial yang diperankan oleh pemimpin. Dalam konteks di sekolah, maka kepala sekolah merupakan pihak yang memiliki tanggungjawab dan peran besar dalam mewujudkan kemajuan sekolah. Pengelolaan pendidikan yang bermutu memerlukan kepemimpinan kepala sekolah secara efektif. Namun, fakta yang ditemukan di lapangan menunjukkan bahwa efektivitas manajerial Kepala Sekolah Menengah Pertama di Tangerang Selatan masih rendah. Berdasarkan hasil survei pendahuluan yang dilakukan dan wawancara dengan pengawas dan pejabat Dinas Penpdidikan Kota Tangerang Selatan, diperoleh gambaran bahwa sekitar 60\% kepala SMP Negeri dan Swasta memenuhi Permendiknas Nomor: 13, Tahun 2007 tentang Standar Kompetensi Kepala Sekolah.

Secara teoretik efektivitas berarti memperoleh produktivitas melalui orang (Cecil dan Rothwell, 2007: 243). Definisi ini memberikan suatu pengertian bahwa manajer yang efektif adalah orang yang mampu memanfaatkan sumber daya manusia yang ada di dalam organisasinya dengan baik dan benar. Efektivitas manajerial juga berhubungan dengan pencapaian hal-hal yang spesifik melalui interaksi berbagai faktor. Hal itu sebagaimana diungkapkan oleh (Pilkington, 1990: 178), efektivitas manajerial berarti mencapai suatu hal yang spesifik melalui interaksi secara bersamaan dari keterampilan, pendidikan, pelatihan, pengalaman, kepribadian dan gaya manajemen.

Manajer dalam sebuah organisasi memiliki banyak peranan strategis yang dibutuhkan untuk kemajuan organisasi. Robbins dan Coulter (2005: 1) menyebutkan terdapat tiga kategori peran manajerial, yaitu peran interpersonal, informasional, dan keputusan. Oleh sebab itu, untuk dapat melaksanakan peran tersebut, manajer harus memiliki keterampilan konseptual, berkomunikasi, efektivitas dan interpersonal.

Dalam mengukur efektivitas manajerial, Leslie et al.(2002: 7) mengajukan lima dimensi. Pertama, mengelola dan memimpin, yang meliputi usaha menetapkan arah, menginspirasi, dan memotivasi serta berhubungan dengan aktivitas seleksi, pengembangan, melatih dan mengelola konflik.Kedua, hubungan interpersonal, yang menunjukkan hubungan dengan sesama dan manajer senior di dalam organisasi. Ketiga, pengetahuan dan inisiatif, yang menunjukkan karakteristik atas pengetahuan luas dan kompetensi profesional dengan atribut personal yang meliputi kepercayaan, kemandirian, dan inisiatif. Keempat, orientasi sukses, yang memperlihatkan orientasi terhadap pencapaian tujuan dan pencapaian hasil yang dikehendaki organisasi. Kelima, kemahiran kontekstual, yaitu fokus eksternal dan mencakup item kemampuan untuk mengelola hubungan eksternal.

Kurangnya efektivitas manajerial kepala sekolah dapat disebabkan oleh 
banyak faktor, antara lain lingkungankerja dan kompetensi profesional.Pertama, faktorlingkunganorganisasi ini merupakan salahsatu faktoryang memengaruhi efektivitas manajer dalam bekerja danmembantupemimpin dalam membangun kepercayaan dankredibilitas. Lingkungan organisasi sekolah tercermin dari sikap warga sekolah. Lingkungankerja yang kondusif memungkinkan setiap individu dalam organisasilebih termotivasi untuk menunjukkan kinerjanya secara unggul. Penelitian sebelumnya yang dilakukan Malik, Ghafoor dan Naseer (2011: 1) juga menguatkan argumen bahwa faktor lingkungan berpengaruh terhadap efektivitas.

Menurut Armstrong (2006: 322), lingkungan organisasi terdiri dari lingkungan eksternal dan internal. Lingkungan eksternal organisasi mencakup lingkungan ekonomi, pasar dan faktor daya saing yang mungkin berpengaruh terhadap organisasi. Lingkunganinternal meliputi misi, nilai, iklim organisasi, gaya manajemen, teknologi, dan proses organisasi yang mempengaruhi fungsi-fungsi dan harus distrukturkan untuk melakukanfungsinya.Penelitianinifokuspada lingkungan internal organisasi, khususnya iklim organisasi. Iklim organisasi dikatakan oleh Gibson, Ivancevich dan Donelly (2002: 12) sebagai seperangkat sifat-sifat dari lingkungan kerja yang dipersepsikan oleh pekerja baik secara langsung maupun tidak langsung dan hal itulah yang diasumsikan menjadi kekuatan utama yang mempengaruhi perilaku para pekerja.Koys dan DeCotiis yang dikutip Burton dan Obel (2004: 140) mengembangkan delapan dimensi iklim organisasi yang membentuk lingkungan organisasi,yaitu otonomi, kebersamaan, kepercayaan, tekanan, dukungan, pengakuan, kewajaran, dan inovasi.

Kedua, faktor kompetensi profesional. Faktor ini juga sangat diperlukan dalam usaha meningkatkan efektivitas kerjakepala sekolah. Dalam Permendiknas Nomor-13, Tahun 2007 tentang Standar Kompetensi Kepala Sekolah disebutkan bahwa kompetensi yang perlu dimiliki kepala sekolah meliputi kompetensi kepribadian, kompetensi manajerial, kompetensi kewirausahaan, kompetensi melakukan supervisi serta kompetensi sosial. Kompetensi merupakan faktor fundamental agar seseorang dapat mengerjakan tugas secara efektif dan efisien. Hasil penelitian Dreyfus (2008: 76) memberikan bukti bahwa kompetensi berpengaruh terhadap efektivitas kerja. Jenis kompetensi yang dapat mempengaruhi efektivitas kerja manajer adalah kompetensi dalam mengelola kelompok dan sensitivitas personal. Kedua kompetensi tersebut terbukti penting dalam meningkatkan efektivitas kerja, khususnya untuk manajer yang dapat dikembangkan sejak dini dan berdasarkan pada pengalaman.

Secara konseptual Willis dan Dubin yang dikutip oleh Elman dan Forrest (2007: 502) mendefinisikan kompetensi profesional sebagai kemampuan untuk berfungsi dalam tugas-tugas yang dipertimbangkan penting dalam sebuah profesi yang diberikan. Lebih lanjut dijelaskan bahwa kompetensi profesional memiliki dua domain, yaitu profisiensi (proficiencies) dan karakteristik umum (general characteristics). Profisiensi merupakan kapabilitas spesifik, termasuk pengetahuan dalam disiplin khusus, keterampilan teknis, dan kemampuan pemecahan masalah. Sementara karakteristik umum meliputi kemampuan intelektual, 
sifat kepribadian, motivasi, sikap dan nilai. Kemudian Cheetham dan Chivers (2005: 77) menjelaskan bahwa kompetensi profesional adalah kepemilikan atas berbagai atribut yang diperlukan untuk kinerja yang efektif dalam profesi, dan kemampuan menyusunnya secara konsisten untuk menghasilkan keseluruhan hasil yang diinginkan.

Masalah dalam penelitian ini dapat dirumuskan sebagai berikut: (1) Apakah lingkungan organisasi berpengaruh langsung terhadap efektivitas manajerial kepala sekolah? (2) Apakah kompetensi manajerial berpengaruh langsung terhadap efektivitas manajerial kepala sekolah?

Berdasarkan uraian di atas;maka penelitian ini memiliki tujuan untuk mengkaji mengenai pengaruh lingkungan organisasi dan kompetensi profesional terhadap efektivitas manajerial kepala sekolah.

\section{METODE PENELITIAN}

Penyelenggaraan penelitian mulai dari tahap persiapan, penyusunan proposal, penyusunan instrumen, uji coba, penelitian lapangan, sampai penulisan laporan penelitian dilakukan mulai Desember 2011 sampai dengan bulan Maret 2013.

Penelitian ini menggunakan pendekatan analisis jalur melalui metode survei. Populasi terjangkau atau populasi target sebagai kerangka sampelnya adalah kepala sekolah yang berjumlah 136 kepala sekolah.

Sampel yang digunakan sebanyak 102 Kepala Sekolah Menengah Pertama di Kota Tangerang Selatan yang diambil dengan teknik simple random sampling. Pengumpulan data penelitian dilakukan dengan kuesioner dalam model skala Likert dan skala peringkat (rating scale).
Analisis data menggunakan analisis statistik deskriptif dan statistik inferensial. Analisis statistik deskriptif meliputi nilai rata-rata, median, modus, standar deviasi, varians, skor maksimum dan minimum, serta distribusi frekuensi dan histrogram. Sementara analisis statistik inferensial menggunakan analisis jalur (path analysis).

Selain itu, juga menguji struktur hubungan yang ditunjukkan dengan seperangkat persamaan, seperti halnya yang ada pada persamaan regresi linear berganda. Persamaan tersebut menggambarkan semua hubungan yang terjadi di antara konstruk yang dilibatkan dalam analisis. Konstruk adalah faktor yang tidak teramati atau faktor laten.

\section{HASIL DAN PEMBAHASAN}

Sebanyak 102 kuesioner yang disebarkan dalam penelitian kembali dengan baik dan layak untuk dianalisis.Berdasarkan data yang diperoleh dilakukan perhitungan statistik deskriptif yang meliputi koefisien korelasi, nilai rata-rata dan standar deviasi. Berdasarkan koefisien korelasi antara variabel bebas dengan variabel terikat, diketahui variabel lingkungan organisasi dan kompetensi profesional memiliki hubungan signifikan dengan efektivitas manajerial.

Pengujian signifikansi regresi efektivitas manajerial atas lingkungan organisasi yang terdapat di Tabel 1 F-hitung sebesar 99,237. Nilai tersebut lebih besar jika dibandingkan nilai $\mathrm{F}$ tabel pada $\mathrm{a}=0,01$ sebesar 6,895, sehingga dapat disimpulkan bahwa persamaan regresi efektivitas manajerial atas lingkungan organisasi adalah sangat signifikan. Dari pengujian linearitas regresi didapatkan nilai F-hitung $=1,520$, sedangkan 
nilai F-tabel pada tingkat kesalahan (a) Karena F-hitung $>$ F-tabel; maka dapat 0,05 dengan $\mathrm{dk}$ pembilang $44 \mathrm{dan} \mathrm{dk}$ disimpulkan bahwa persamaan regresi penyebut 56 adalah 1,593. Nilai F-hitung < efektivitas manajerial atas kompetensi F-tabel, sehingga dapat disimpulkan bahwa persamaan regresi efektivitas manajerial atas lingkungan organisasi berbentuk linear.

Demikian pula pengujian signifikansi regresi efektivitas manajerial atas kompetensi profesional yang terdapat pada tabel 2 diperoleh nilai F-hitung 92,119, sedangkan nilai $\mathrm{F}$-tabel pada $\mathrm{a}=0,01$ sebesar 6,895 . profesional adalah signifikan. Pengujian linearitas regresi diperoleh nilai F-hitung 1,532 dan nilai F-tabel pada a 0,05 dengan dk pembilang 42 dan dk penyebut 58 adalah 1,593. Nilai F-hitung < nilai F-tabel, sehingga dapat disimpulkan bahwa persamaan regresi efektivitas manajerial atas kompetensi profesional berbentuk linear.

Tabel 1. Analisis Varians (ANAVA) untuk Uji Signifikansi dan Linearitas Regresi Efektivitas Manajerial atas Lingkungan Organisasi

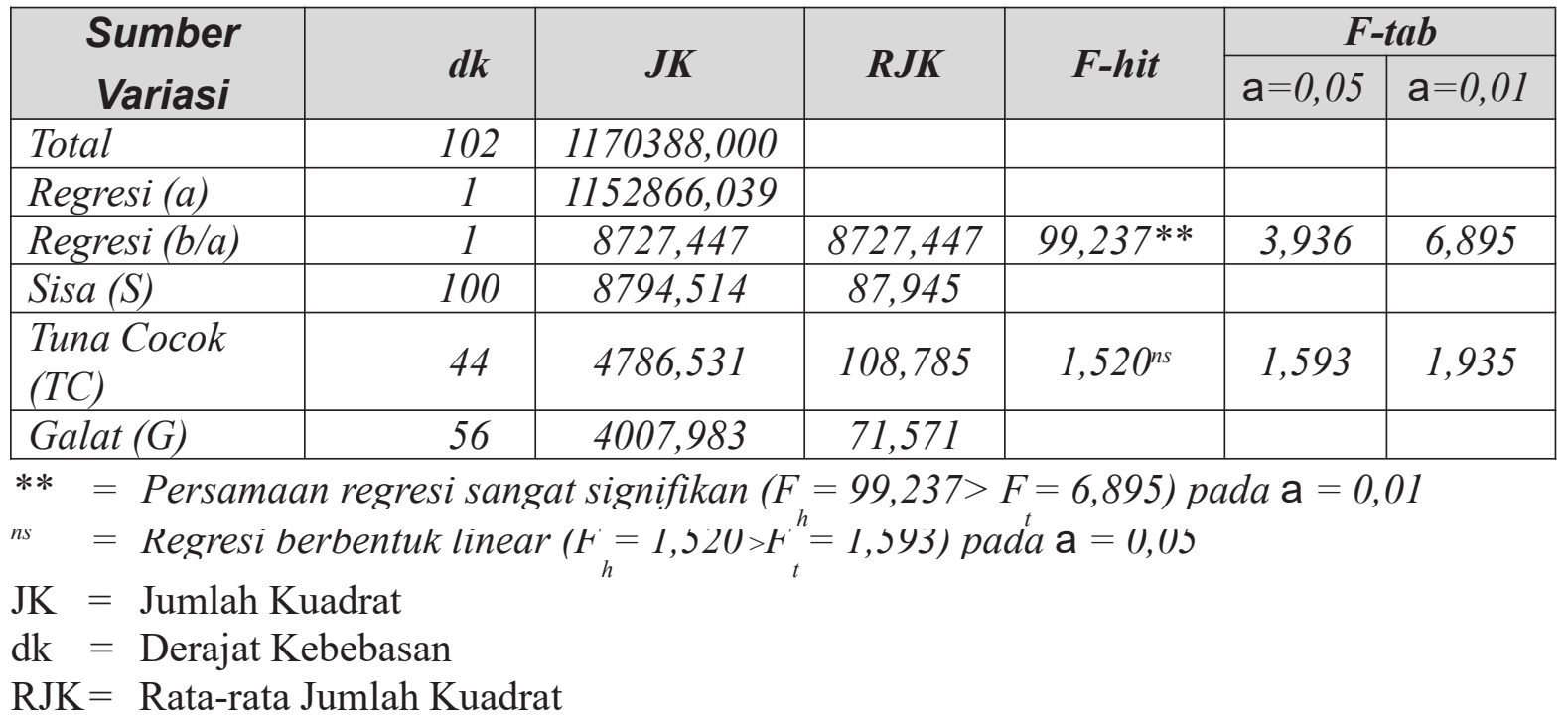

Tabel 2. Analisis Varians (ANAVA) untuk Signifikansi dan Linearitas Regresi Efektivitas Manajerial atas Kompetensi Profesional

\begin{tabular}{|c|c|c|c|c|c|c|}
\hline \multirow{2}{*}{ Sumber Variasi } & \multirow{2}{*}{ dk } & \multirow{2}{*}{ JK } & \multirow{2}{*}{ RJK } & \multirow{2}{*}{ F-hit } & \multicolumn{2}{|c|}{ F-tab } \\
\hline & & & & & $a=0,05$ & $a=0,01$ \\
\hline Total & 102 & 1170388,000 & & & & \\
\hline Regresi (a) & 1 & 1152866,039 & & & & \\
\hline Regresi (b/a) & 1 & 8401,597 & 8401,597 & $92,119 * *$ & 3,936 & 6,895 \\
\hline Sisa $(\mathrm{S})$ & 100 & 9120,364 & 91,204 & & & \\
\hline Tuna Cocok (TC) & 42 & 4796,330 & 114,198 & $1,532^{\mathrm{ns}}$ & 1,593 & 1,934 \\
\hline Galat $(\mathrm{G})$ & 58 & 4324,033 & 74,552 & & & \\
\hline
\end{tabular}

$* * \quad=$ Persamaan regresi sangat signifikan $(\mathrm{F}=92,119>\mathrm{F}=6,895)$ pada $\mathrm{a}=0,01$

ns $\quad=$ Kegresi berbentuk Iinear $\left(\mathrm{F}=1,532<\mathrm{F}_{\mathrm{t}}^{\mathrm{h}}=1,593\right)$ pada $\mathrm{a}=0,05$

$\mathrm{JK}=$ Jumlah Kuadrat

$\mathrm{dk}=$ Derajat Kebebasan

RJK= Rata-rata Jumlah Kuadrat 
Dari Tabel 3 dapat dilihat Koefisien korelasi antara lingkungan organisasi dengan efektivitas manajerial sebesar 0,706 signifikan pada tingkat kesalahan 1\%. Menurut kriteria Guildford, koefisien korelasi 0,706 berarti antara lingkungan organisasi dengan efektivitas manajerial memiliki hubungan yang terkategori sedang atau kuat. Variabel kompetensi profesional dengan efektivitas manajerial memiliki koefisien korelasi 0,692 yang signifikan pada tingkat kesalahan $1 \%$ dan memiliki kategori hubungan cukup kuat. Sementara itu, untuk variabel lingkungan organisasi dengan kompetensi profesional memiliki koefisien korelasi 0,559 signifikan pada tingkat kesalahan 1\% dan memiliki kategori hubungan cukup kuat. deviasi 14,656, variabel kompetensi profesional memiliki rata-rata 100,098 dengan standar deviasi 13,904, dan variabel efektivitas manajerial memiliki rata-rata 106,314 dengan standar deviasi 13,171.

Pengujianstatistik untuk melihat pengaruh lingkungan organisasi dan kompetensi profesional terhadap efektivitas mananjerial, perhitungannya dilakukngan dengan bantuan sofware LISREL 8.0.Hasil yang diperoleh dari perhitungan LISREL meliputi koefisien jalur (Gambar 1), dan indeks kesesuaian model. Koefisien jalur untuk melihat kekuatan pengaruh, t-hitung untuk menguji signifikansi, dan indeks kesesuaian untuk melihat apakah model yang diuji sesuai dengan teori.

Tabel 3. Korelasi, Rata-Rata dan Standar Deviasi Variabel Penelitian

\begin{tabular}{|l|r|r|r|}
\hline Variabel & $\mathbf{1}$ & $\mathbf{2}$ & \multicolumn{1}{|c|}{$\mathbf{3}$} \\
\hline 1. Lingkungan Organisasi & 1 & & \\
\hline 2. Kompetensi Profesional & $0,559^{* *}$ & 1 & 1 \\
\hline 3. Efektivitas Manajerial & $0,706^{* *}$ & $0,692^{* *}$ & 106,314 \\
\hline Mean & 101,490 & 100,098 & 13,171 \\
\hline Standard Deviation & 14,656 & 13,904 & \\
\hline
\end{tabular}

** Correlation is significant at the 0.01 level (2-tailed).

Statistik deskriptif lainnya adalah nilai rata-rata dan standar deviasi. Nilai rata-rata yang diperoleh untuk variabel lingkungan organisasi adalah 101,490 dengan standar
Gambar 1 memperlihatkan koefisien jalur pengaruh variabel lingkungan organisasi dan kompetensi profesional terhadap efektivitas manajerial. Masing- 


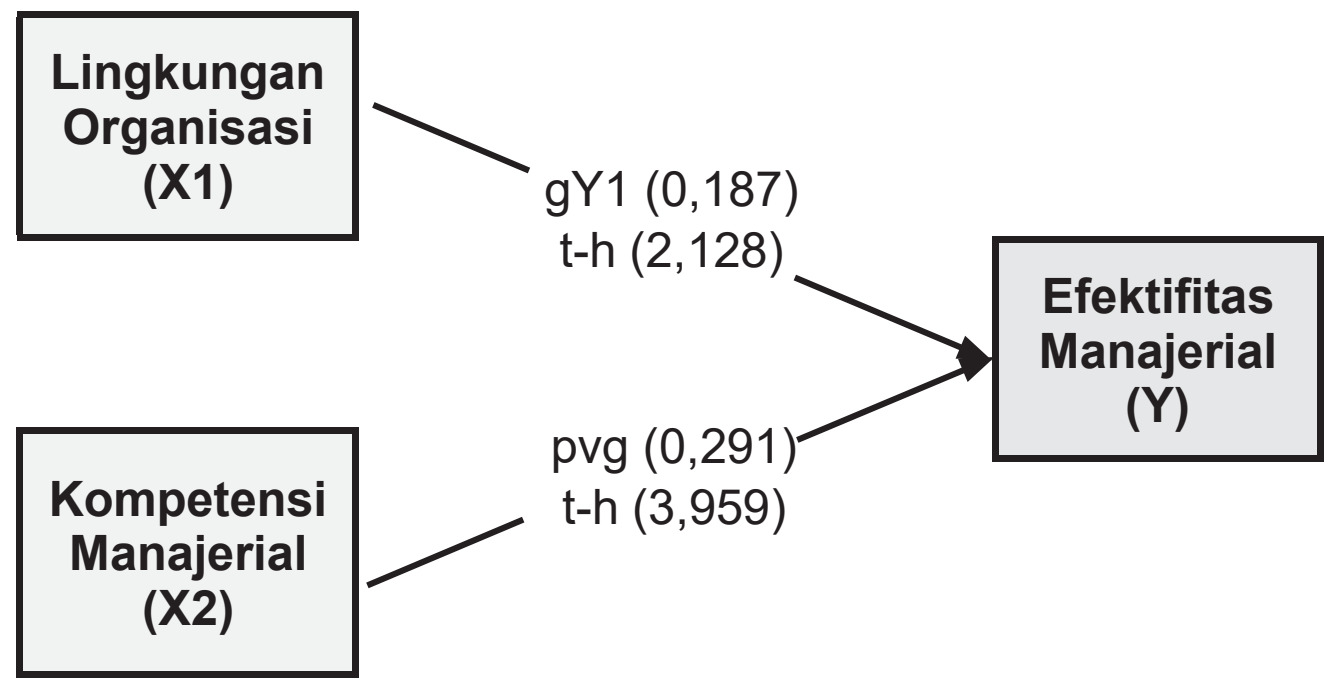

Gambar 1.

Koefisien Jalur dan t hitung Pengaruh Lingkungan Organisasi, Kompetensi manajerial, Komitmen Kerja dan Budaya Kerja sama Terhadap Efektivitas Manajerial

masing variabel laten diwakili oleh indikatornya (variabel terukur). Variabel lingkungan organisasi sebelumnya terdiri dari 8 indikator dan berdasarkan perhitungan terdapat satu indikator yang tidak valid, sehingga menyisakan 7 indikator valid. Sementara itu,untuk variabel kompetensi profesional kepala sekolah dan efektivitas manajerial semua indikatornya valid.

Koefisien jalur yang diperoleh untuk pengaruh lingkungan organisasi terhadap efektivitas manajerial sebesar 0,187 dengan t-hitung 2,128. Nilai t kritisnya (t-tabel) sebesar 1,665. Dengan demikian, t-hitung $(2,128)>$ t-tabel $(1,665)$, sehingga dapat disimpulkan bahwa pengaruh lingkungan organisasi terhadap efektivitas manajerial adalah signifikan.

Kemudian untuk pengaruh kompetensi profesional terhadap efektivitas manajerial diperoleh koefisien jalur sebesar 0,291 dengan t-hitung 3,959. Diketahui t-hitung $(3,959)>$ t-tabel $(1,665)$, sehingga dapat disimpulkan bahwa pengaruh kompetensi profesional terhadap efektivitas manajerial adalah signifikan. Berdasarkan koefisien pengaruhnya, lingkungan organisasi dan kompetensi profesional memiliki koefisien positif. Hasil ini menunjukkan bahwa peningkatan lingkungan organisasi dan kompetensi profesional akan memberikan dampak positif bagi peningkatan efektivitas manajerial.

Perhitungan indeks kesesuaian model (goodness of fit index) diperoleh Root Mean Square Error of Approximation (RMSEA)= 0,044, P-value Chi Square $=0,032$, Normed Fit Index $(N F I)=0,94$, Non-Normed Fit Index $(N N F I)=0,98$, Parsimony Normed Fit Index $(P N F I)=0,82$, Comparative Fit Index $(C F I)=$ 0,99, Incremental Fit Index (IFI) $=0,99$, Relative Fit Index (RFI) =0,93, dan Goodness of Fit Index $(G F I)=0,82$. Dari sejumlah indeks kesesuaian model tersebut, indeks yang tergolong good fit adalah RMSEA $(<0,05)$, NFI $(\geq 0,9)$, NNFI $(\geq 0,9)$, CFI $(\geq$ $0,9)$, IFI $(\geq 0,9)$, RFI $(\geq 0,9)$, sedangkan yang tergolong marginal fit adalah PNFI 
dan GFI. Sementara P-value Chi Square tidak memenuhi kriteria. Berdasarkan hasil ini; maka dapat disimpulkan bahwa model empirik pengaruh lingkungan organisasi dan kompetensi profesional terhadap efektivitas manajerial sesuai dengan model teoritisnya.

Hasil pengujian statistik dalam penelitian ini menunjukkan bahwa lingkungan organisasi berpengaruh signifikan terhadap efektivitas manajerial. Penelitian ini mendukung acuan teoritik dan penelitian terdahulu. Efektivitas manajerial seseorang juga tampak dari kualitas kepemimpinannya, sehingga semakin efektif kepemimpinan yang diperankan maka juga berarti semakin efektif fungsi manajerial yang dilakukan. Terkait dengan hal ini sebagaimana dikemukakan oleh Militello dan Schwalberg (2002: 29) ada interaksi antara lingkungan organisasi dengan kualitas kepemimpinan karyawan, "of course there is interaction between organizational environment and employees' leadership qualities." Pernyataan lebih dijelas dikemukakan oleh Boyatzis sebagaimana dikutip oleh Bellavita(1990: 174): "research generally indicates that managerial effectiveness is associated with personal and environmental factors. Among these are the individual's competencies, the job's demands, the specific actions or behavior of the manager and the organizational environment." Dari pernyataan ini tampak jelas bahwa efektivitas manajerial berkaitan erat dengan lingkungan organisasi.

Hasil penelitian terdahulu juga memberikan bukti bahwa lingkungan organisasi berperan dalam mempengaruhi efektivitas manajerial. Hal ini dapat dilihat dalam penelitian Osborn dan Hunt (1974: 231) tentang kaitan lingkungan organisasi dengan efektivitas organisasi. Hasilnya menunjukkan bahwa aspek lingkungan organisasi, ketergantungan lingkungan, dan interaksi organisasional baik secara sendiri-sendiri maupun secara berinteraksi berhubungan signifikan secara positif dengan efektivitas organisasi. Hasil itu juga didukung oleh penelitian Malik, Ghafoor dan Naseer (2011: 1)yang antara lain menunjukkan bahwa faktor lingkungan berpengaruh terhadap lingkungan organisasi.Dengan hasil demikian- maka hasil penelitian semakin mempertegas teori-teori dan penelitian terdahulu yang membuktikan bahwa lingkungan organisasi berpengaruh terhadap efektivitas manajerial.

Hasil pengujian secara statistik juga membuktikan bahwa kompetensi profesional kepala sekolah berpengaruh langsung positif dan signifikan terhadap efektivitas manajerial kepala sekolah. Hasil tersebut menunjukkan bukti secara empiris bahwa peningkatan kompetensi profesional kepala sekolah akan memberikan dampak terhadap meningkatnya efektivitas manajerial kepala sekolah. Temuan ini pada prinsipnya dapat dimengerti, mengingat hasil kerja yang baik hanya dapat dicapai jika didasari dengan kompetensi yang memadai. Tanpa adanya kompetensi yang memadai maka suatu pekerjaan tidak dapat diselesaikan dengan maksimal. Demikian pula dengan peran-peran manajerial, maka tidak akan efektif jika dalam pelaksanaannya tidak didasarkan oleh kompetensi yang mumpuni.

Temuan yang menunjukkan bahwa kompetensi profesional berpengaruh terhadap efektivitas manajerial pada dasarnya mendukung teori yang telah ada dan penelitian sebelumnya. Keterkaitan secara teoritis antara faktor kompetensi 
dengan efektivitas manajerial dikemukakan oleh Murphy dan Saalk (1990: 79):Important variable such as the ability to judge the situational appropriateness of behavior, the ability to engage in specific behavior, feelings of competence and perceptions that one will achieve his or her goal, are likely predictors of managerial effectiveness. Teori tersebut juga diperkuat oleh kajian dari Dreyfus (2008: 76) yang menyimpulkan:These were similar enough to collapse into two competencies: managing groups and interpersonal sensitivity. For the highly effective managers who demonstrated these two competencies, development of their capability began at young ages and prior to work experience. Effective and regular use of the two competencies occurred later in life and typically as a result of taking on leadership roles outside the work setting.Dari pernyataan tersebut jelas terlihat bahwa perasaan kompetensi merupakan salah satu variabel yang dapat menjadi prediktor efektivitas manajerial.Pengaruh kompetensi profesional terhadap efektivitas manajerial juga telah dibuktikan melalui penelitian terdahulu, seperti yang dilakukan Dreyfus (2008: 76) yang hasilnya menunjukkan bahwa jenis kompetensi yang dapat mempengaruhi efektivitas kerja manajer adalah kompetensi dalam mengelola kelompok dan sensitivitas personal. Kedua kompetensi tersebut terbukti penting dalam meningkatkan efektivitas kerja, khususnya untuk manajer yang dapat dikembangkan sejak dini dan berdasarkan pada pengalaman.Dengan demikian, hasil penelitian semakin memperkuat teoriteori dan hasil penelitian terdahulu yang menjelaskan tentang pentingnya kompetensi profesional dalam meningkatkan efektivitas manajerial.
Dengan merujuk pada hasil penelitian tersebut,maka lingkungan organisasi yang kondusif akan mengakibatkan peningkatan efektivitas manajerial, sehingga perlu dilakukan empat upaya: (1) Dinas Pendidikan memberikan arahan kepada kepala sekolah tentang bagaimana menciptakan lingkungan organisasi sekolah sebagai tempat yang kondusif untuk bekerja dan belajar, (2) Dinas Pendidikan melakukan evaluasi pada setiap sekolah untuk melihat kualitas lingkungan organisasi sekolah, (3) Kepala sekolah diberikan otonomi yang cukup dalam mengelola sekolahnya, (4) Kepala sekolah berupaya mengevaluasi aspek-aspek yang dapat mempengaruhi iklim organisasi sekolah; seperti struktur tugas guru, imbalan, latihan dan pengembangan, keselamatan, keamanan, dan keluwesan organisasi.

Demikian pula dengan kompetensiprofesional kepala sekolah yang positif akan mengakibatkan peningkatan efektivitas manajerial, sehingga perlu dilakukan lima upaya: (1) Kepala sekolah meningkatkan kemampuan dalam menjalankan fungsinya sebagai edukator, (2) Kepala sekolah mengembangkan kemampuan dalam menjalangkan fungsinya sebagai manajer, (3) Kepala sekolah mengembangkan kemampuan sebagai administrator dengan berusaha meningkatkan kompetensinya untuk mengelola kurikulum, mengelola administrasi kearsipan, dan administrasi keuangan sekolah, (4) Kepala sekolah berusaha mengembangkan kemampuan sebagai supervisor. Kepala sekolah memiliki penekanan pada tindakan edukasi dalam melakukan supervisi dan bukan hanya sekedar untuk mencari kesalahan bawahan, dan (5) Kepala sekolah mengembangkan 
kemampuan dalam menjalankan fungsinya sebagai motivator. Oleh karena itu, kepala sekolah harus memiliki strategi yang tepat untuk memberikan motivasi kepada para pendidik dan tenaga kependidikan dalam melakukan berbagai tugas dan fungsinya.

Penelitian ini diupayakan secara maksimal untuk mencapai kualitas hasil penelitian yang baik. Namun, tetap memiliki sejumlah keterbatasan. Pertama, dalam mengukur setiap variabel penelitian menggunakan metode self appraisal, yang memungkinkan responden menjawab tidak jujur, sehingga dapat mempengaruhi validitas data yang dikumpulkan. Kedua, penelitian ini hanya melibatkan dua variabel bebas, yaitu lingkungan organisasi dan kompetensi manajerial untuk melihat faktor yang mempengaruhi efektivitas manajerial. Padahal, masih ada faktor-faktor lain yang secara teori mempengaruhi efektivitas manajerial. Dengan hanya mengambil dua faktor tersebut- maka tidak dapat diketahui faktor lain yangmempengaruhi efektivitas manajerial.

\section{SIMPULAN DAN SARAN}

\section{Simpulan}

Hasil penelitian ini menunjukkan bahwa lingkungan organisasi berpengaruh langsung positif terhadap efektivitas manajerial sebesar 0,187 dengan t-hitung 2,128. Nilai t kritisnya (t-tabel) sebesar 1,665. Dengan demikian, thitung $(2,128)>$ t-tabel $(1,665)$. Temuan inimemberikan makna bahwa lingkungan organisasi yang kondusif akan memberikan dampak terhadap meningkatnya efektivitas manajerial. Kompetensi profesional kepala sekolah juga berpengaruh langsung positif terhadap efektivitas manajerial kepala sekolah. Hasil ini menunjukkan bahwa peningkatan kompetensi profesional kepala sekolah akan memberikan dampak terhadap meningkatnya efektivitas manajerial kepala sekolah.

Dengan hasil yang demikian, maka disarankan agar lingkungan organisasi sekolah perlu diperbaiki karena terbukti mampu memberikan pengaruh positif terhadap efektivitas manajerial. Aspek lingkungan organisasi yang perlu dibenahi terutama menyangkut hubungan dan komunikasi antarwarga sekolah. Oleh karena itu, sekolah harus menciptakan suasana kekerabatan dan komunikasi yang harmonis agar tidak terjadi konflik-konflik yang menyebabkan suasana organisasi sekolah tidak kondusif. Dalam hal ini kepala sekolah memiliki peranan penting untuk menciptakan suasana sekolah yang kondusif, sehingga perlu memiliki kemampuan dalam mengelola konflik secara efektif dan membangun komunikasi yang harmonis dengan seluruh warga sekolah. Kepala sekolah juga perlu menghidupkan suasana toleransi, saling menghargai, dan saling menghormati antarwarga sekolah, sehingga dapat tercipta suasana sekolah yang kondusif.

Kepala sekolah supaya terus berusaha meningkatkan kompetensi profesionalnya agar dapat memberikan kontribusi yang lebih besar dalam meningkatkan efektivitas manajerial, budaya kerja sama dan komitmen kerjanya. Usaha ke arah itu dapat dilakukan dengan meningkatkan kemampuan dalam menjalankan fungsi utamanya sebagai manajer, edukator, administrator, supervisor, dan motivator. Oleh karena itu, kepala sekolah perlu bersikap proaktif dalam meningkatkan kompetensi tersebut 
dengan cara mengikuti pelatihan-pelatihan atau seminar kepemimpinan, pelatihan kecerdasan emosional, banyak membaca buku-buku, dan berdiskusi dengan rekanrekan kepala sekolah. Untuk itu, dukungan
Pemerintah Daerah dan Dinas Pendidikan sangat dibutuhkan dalam memberikan arahan dan pelatihan-pelatihan khusus untuk meningkatkan kompetensi profesional kepala sekolah.

\section{PUSTAKA ACUAN}

Armstrong, Michael.,2006.A Handbook of Personnel Management Practice, London: Kogan Page. ok

Bellavita, Christopher,. 1990.How Public Organizations Work: Learning from Experience, New York: Praeger Publishers sok

Burton, Richard M. and Borge Obel.-2004.Strategic Organizational Diagnosis and Design: The Dynamics of FitInformation and Organization Design Series. London: Springer.ok

Cecil, Robert D., danWilliam J. Rothwell. 2007.,Next Generation Management Development: The Complete Guide and Resource, San Fransisco: John Wiley \& Sons, Inc.ok

Cheetham, Graham and Geoff Chivers. 2005.,Professions, Competence, and Informal Learning, Massachusetts: Edward Edgar Publishing Limited. ok

Dreyfus, Christine R.,2008. "Identifying competencies that predict effectiveness of R\&D managers", Journal of Management Development, Vol. 27 No. 1, 76-91.Ok 1

Elman, Nancy S. dan Linda Forrest,.2007."From trainee impairment to professional competence problems: Seeking new terminology that facilitates effective action", Professional Psychology: Research and Practice, Vol. 38, No. 5, 501-509.0k 2

Gibson, James L., Jhon M. Ivancevich and James H. Donelly., 2002.Organization: Behavior, Structure, Processes. Texas: Business Publication, Inc., 2002.ok

Hair, Joseph F., R.E. Anderson, R.L. Tatham, \& W.C. Black,Multivariate Data Analysys, New Jersey: Prentice Hall, 2010.

Leslie, Jean Brittain, Maxine Dalton, Christopher Ernst and Jennifer Deal. 2002,“"Managerial effectiveness in a global context", North Carolina: Center for Creative Leadership.ok

Militello, Frederick C. dan Michael D. Schwalberg,. 2002.Leverage Competencies: The Key To Financial Leadership Success, New Jersey: Financial Executive Research Foundation, Inc.ok

Murphy, Kevin R. and Frank E. Saalk,1990.Psychology in Organizations: Integrating Science and Practice, New Jersey: Lawrence Erlbaum Associates, Inc-ok

Osborn, Richard N. and James G. Hunt,1974. "Environment and Organizational Effectiveness", Administrative Science Quarterly,Vol. 19, No. 2, 231-246.Ok 3

Pilkington, William F.,1990.Understanding Effective Management in Christopher Bellavita (ed),How Public Organizations Work: Learning from Experience, New York: Praegers Publishers.ok 
Robbins, Stephen P. dan Mary Coulter., 2005.Management, New Jersey: Pearson Education Inc.Ok

Malik, Ghafoor \& Nasser. (2011).Organizational Effectiveness: A case Study of Telecommunication and banking Sector of Pakistan. Far East Journal of Psychology and Business Vol. 2 No 1,

....,Permendiknas Nomor: 13, Tahun 2007 tentang Standar Kompetensi Kepala Sekolah, Jakarta : Kemdikbud 